\title{
Az elhízás jelenlegi és prognosztizált betegségterhe a magyarországi romák körében I.
}

\author{
Kiss Anna ${ }^{1}$. Andó Réka dr. ${ }^{2}$. Fritz Péter dr. ${ }^{3}$ - Lakner Zoltán dr. ${ }^{1}$ \\ ${ }^{1}$ Szent István Egyetem, Élelmiszertudományi Kar, Élelmiszeripari Gazdaságtan Tanszék, Budapest \\ ${ }^{2}$ Semmelweis Egyetem, Általános Orvostudományi Kar, Fül-Orr-Gégészeti és Fej-Nyaksebészeti Klinika, Budapest \\ ${ }^{3}$ Miskolci Egyetem, Egészségügyi Kar, Miskolc
}

Bevezetés: A magyarországi lakosság növekvő arányú részét képezi a roma populáció. Többszörösen hátrányos helyzetük egyik következménye a helytelen táplálkozás, mely számos esetben vezet elhízáshoz és az elhízás társbetegségeinek magas prevalenciájához.

Célkitüzés: Primer antropometriai adatok gyújtése alapján meghatározzuk a hazai roma kisebbségben a túlsúly és az elhízás előfordulási gyakoriságát, majd ezek és a fellelhető hivatalos statisztikai adatok alapján becslést és hosszú távú prognózist készítünk az elhízás okozta fóbb megbetegedések betegségterheire vonatkozóan, nemek és korcsoportok szerinti bontásban.

Módszer: A szerzők a nemzetközi és hazai adatforrások alapján, a Spectrum 5.0 szoftverrel elörejelzést készítettek a roma populáció várható létszámára vonatkozóan, majd antropometriai mérések alapján, a Dynamic Modeling for Health Impact Assessment szoftver alkalmazásával prognosztizálták az elhízás okozta fóbb megbetegedések hosszú távú incidenciáját és prevalenciáját.

Eredmények: A következő évtizedekben a roma lakosság száma a jelenlegi értéknek legalább a duplájára nő; a magyarországi romák körében a túlsúly és az elhízás prevalenciája nagyobb a teljes magyar lakossággal összehasonlítva. A következő évtizedekben az elhízáshoz kapcsolódó társbetegségek prevalenciája a nók esetében 6 ezerról 26 ezerre, a férfiaknál közel 6 ezerről több mint 17 ezerre nő. Az elhízottak körében a társbetegségek gyakorisága a jelenlegi érték több mint a háromszorosára emelkedik.

Következtetések: Az egészségügyi ellátórendszernek fel kell készülnie az elhízás társbetegségeinek gyorsan növekvő arányú kezelésére a hazai romák körében. A helyzet hosszú távú javítása átgondolt prevenciós és intervenciós programok kialakítását teszi szükségessé.

Orv Hetil. 2019; 160(28): 1097-1104.

Kulcsszavak: elhízás, roma populáció, prevalencia, egészségügyi hatásvizsgálat

\section{Current and future burden of obesity at the Hungarian Roma population I}

Introduction: The Roma population rapidly gains in importance in the social structure of Hungary. An adverse consequence of the multiple disadvantageous position of this minority is the unhealthy nutrition, which leads to obesity and high prevalence of its co-diseases.

Aim: Based on primer anthropometric data collection, we will determine the nutritional status of the Hungarian Roma population, then on the basis of official statistical data, an estimation and prognoses will be prepared on the disease burden of obesity according to genders and age.

Method: A long-range forecast of the population size of the Roma minority's prognosis has been prepared on the basis of official statistics and time-series by Spectrum 5.0 demographic software. On this basis, applying the Dynamic Modeling for Health Impact Assessment software, we have prepared a forecast for the incidence and prevalence of the most important diseases attributable to obesity.

Results: In the next decades, the number of the Roma population will be doubled, but there is a high level of uncertainty of different forecasts. The nutritional status of the Hungarian roma population is less favorable, than the indicators, characterizing the Hungarian population as a whole. In the next half a century, the prevalence of co-morbidities of obesity will be increasing from 6 thousand up to 26 thousand in the case of women, while in the case of men from nearly 6 thousand up to 17 thousand. 
Conclusions: The rapidly increasing number of the Roma population is an increasing challenge for the Hungarian healthcare system, which highlights the importance of evidence-based prevention and intervention programs.

Keywords: obesity, Roma population, prevalence, health impact assessment

Kiss A, Andó R, Fritz P, Lakner Z. [Current and future burden of obesity at the Hungarian Roma population I]. Orv Hetil. 2019; 160(28): 1097-1104.

(Beérkezett: 2019. február 3.; elfogadva: 2019. március 9.)

\section{Rövidítések}

$\mathrm{BMI}=($ body mass index $)$ testtömegindex; DYNAMO-HIA = (Dynamic Modeling for Health Impact Assessment) Dinamikus Egészségügyi Hatásvizsgálat Modellezés; EU = (European Union) Európai Unió; HDL = (high-density lipoprotein) magas sûrúségú lipoprotein; HIV = (human immunodeficiency virus) emberi immunhiány-előidéző vírus; $\mathrm{KSH}=$ Központi Statisztikai Hivatal; WHO $=$ (World Health Organization) Egészségügyi Világszervezet

A roma lakosság gyakran szembesül diszkriminációval és társadalmi kirekesztéssel, s ez közvetett hatással bír az egészségi állapotukra; Európában a roma lakosság egészségi állapota rosszabb, összehasonlítva a nem roma lakossággal [1]. A szakirodalom evidenciának tekinti, hogy „a roma egyike Európa legnagyobb és leginkább veszélyeztetett nemzeti kisebbségeinek” [2, 3]. A témakör tudományos megismerését nehezíti, hogy maga a roma mint etnikai besorolás sok esetben nehezen értelmezhető és azonosítható [4]. Az Európai Unió mintegy 12-15 millió fơre becsüli a cigányok számát az Unióban [5], többségük az EU közép- és kelet-európai államaiban, Bulgáriában, Romániában, Szlovákiában, Magyarországon, Csehországban és Szlovéniában él. A roma populációra jellemző közös probléma a szegénység, az oktatáshoz való korlátozott hozzáférés, a magas munkanélküliség, a társadalmi kirekesztés, a rossz egészségügyi állapot és az ebból adódó rövid várható élettartam $[6,7]$.

A kedvezőtlen szociodemográfiai helyzet, a roma háztartások alacsony élelmezésbiztonsága és a táplálkozási bizonytalanság a fejlett országokban élő hátrányos helyzetű csoportoknál irracionális élelmiszerfogyasztási szerkezethez társul. A romák táplálkozására jellemző, hogy nagyobb arányban fogyasztanak gabonából készült élelmiszereket, hozzáadott cukortartalmú üdítőitalokat és nagy energiasűrüségú élelmiszereket, valamint kevesebb zöldséget, gyümölcsöt, tejet és tejterméket fogyasztanak [8]. Az energiaszükségletet meghaladó energiabevitel és a fizikai aktivitás hiánya hosszú távon túlsúly, illetve elhízás és az abból adódó társbetegségek kialakulásához vezet körükben, amelyek már gyermekkorban is fellépnek $[9,10]$. Az európai népesség demográfiai különbségeit figyelembe véve elmondható, hogy a roma közösségek egyaránt nagyobb arányban szenvednek krónikus betegségekben (például asztma, depresszió, HIV) és krónikus, nem fertőző betegségekben (például 2-es típusú diabetes mellitus, cardiovascularis betegségek, magas vérnyomás) [11]. Közép- és kelet-európai vizsgálatok eredményei igazolják a 2-es típusú diabetes mellitus, a hyperlipidaemia, a koszorúér-betegség, a korai myocardialis infarctus és az elhízás nagy prevalenciáját romáknál [12]. Az elhízás prevalenciáját az európai roma kisebbségek körében az 1. táblázat mutatja [13-21].

Kósa ás mtsai (2014) a magyar roma populáció körében végzett kutatási eredményei azt mutatták, hogy a centrális típusú elhízás, a magas vérnyomás és a megemelkedett trigliceridszint a magyarországi roma és nem roma lakosság között nem mutat statisztikailag igazolható különbséget, de éhomi plazmaglükózszint, 2-es típusú diabetes mellitus, csökkent HDL-koleszterin-szint és a kezelt zsíranyagcsere-betegségek szignifikánsan gyakrabban fordultak elő a roma populáció minden vizsgált korcsoportjában [22].

\section{Célkitüzések}

A jelen tanulmánynak három célja van: 1) szakirodalmi források alapján felvázoljuk a magyarországi cigány ${ }^{1}$ (roma) közösség mint társadalom-orvostani szempontból kiemelt figyelmet érdemlő, sajátos etnikum tápláltsági állapotának néhány, további vizsgálataink szempontjából releváns jellemzőjét; 2) bemutatunk egy olyan, felhasználási területén a legkorszerübbnek tekinthető algoritmust és az erre alapuló szoftvert, melynek segítségével képesek vagyunk hosszú távra előre jelezni egy-egy populáció fóbb betegségcsoportjainak prevalenciáját és incidenciáját a különböző kockázati tényezők (például elhízás, dohányzás, alkoholfogyasztás) függvényében; 3 ) ezen szoftver segítségével előrejelzést készítünk az elhízás okozta betegségteher alakulására vonatkozóan a magyarországi roma kisebbség esetén.

${ }^{1}$ A roma/cigány mint nemzetiségi megjelölés elfogadottsága nagyon különböző az egyes roma/cigány közösségekben. A leginkább korrekt megoldás a roma/cigány megnevezés lenne, de az egyszerüség kedvéért, követve a magyar tudományos kutatás és közlés gyakorlatát (például Lukács-Feith, 2016), a jelen munkában a roma és a cigány megnevezést egymás szinonimáiként használjuk. 
A roma lakosság tápláltsági állapotát felmérő európai kutatások eredményei: a túlsúly és az elhízás prevalenciája testtömegindex alapján, időrend sorrendben

\begin{tabular}{|c|c|c|c|c|c|}
\hline Forrás & Földrajzi régió & \multicolumn{4}{|l|}{ Eredmény } \\
\hline $\begin{array}{l}\text { Krajcovicova-Kudlackova et al. (2004) } \\
\text { [13] }\end{array}$ & Szlovákia & \multicolumn{4}{|c|}{$\begin{array}{l}\text { A } 18 \text { év feletti roma lakosság BMI-je } 26,2 \pm 5 \text {, a } 30 \text { feletti BMI-vel } \\
\text { rendelkezők aránya } 32 \%\end{array}$} \\
\hline \multirow[t]{2}{*}{ Zajc et al. (2006) [14] } & Horvátország & \multicolumn{2}{|c|}{ 18-24 év közötti férfiak } & \multicolumn{2}{|c|}{ 18-24 év közötti nők } \\
\hline & & \multicolumn{2}{|l|}{$23 \pm 4,3$} & \multicolumn{2}{|l|}{$22 \pm 4,1$} \\
\hline Gallagher et al. (2009) [15] & Szerbia & \multicolumn{4}{|c|}{$35 \%$ túlsúlyos vagy elhízott } \\
\hline \multirow[t]{2}{*}{ Gualdi-Russo et al. (2009) [16] } & Nyugat-balkáni romák & \multicolumn{2}{|l|}{ Felnőtt férfiak } & \multicolumn{2}{|l|}{ Felnőtt nők } \\
\hline & & \multicolumn{2}{|l|}{$24,6 \pm 4,3$} & \multicolumn{2}{|l|}{$25,9 \pm 5,2$} \\
\hline Carrasco-Garrido et al. (2010) [17] & Spanyolország & \multicolumn{4}{|c|}{$\begin{array}{l}\text { A } 30 \text { feletti BMI-vel rendelkezó roma nők aránya } 24,45 \% \text {, ez a spanyol } \\
\text { átlag kétszerese }\end{array}$} \\
\hline \multirow[t]{2}{*}{ Babinska et al. (2013) [18] } & Szlovákia & \multicolumn{2}{|l|}{ Felnőtt férfi } & \multicolumn{2}{|l|}{ Felnőtt nő } \\
\hline & & \multicolumn{2}{|l|}{$26,79 \pm 5,94$} & \multicolumn{2}{|c|}{$26,44 \pm 6,01$} \\
\hline \multirow[t]{13}{*}{ Zeljko et al. (2013) [19] } & Horvátország & Életkori csoportok & BMI-kategória & Férfiak (\%) & Nők (\%) \\
\hline & & \multirow[t]{3}{*}{$18-34$} & $<25$ & 60,9 & 69,5 \\
\hline & & & $25-29,99$ & 25,0 & 16,2 \\
\hline & & & $>30$ & 14,1 & 14,3 \\
\hline & & \multirow[t]{3}{*}{$35-49$} & $<25$ & 30,8 & 44,7 \\
\hline & & & $25-29,99$ & 40,4 & 32,9 \\
\hline & & & $>30$ & 28,8 & 22,4 \\
\hline & & \multirow[t]{3}{*}{$50-64$} & $<25$ & 40,9 & 37,3 \\
\hline & & & $25-29,99$ & 45,5 & 25,4 \\
\hline & & & $>30$ & 13,6 & 37,3 \\
\hline & & \multirow[t]{3}{*}{$65+$} & $<25$ & 72,7 & 40,0 \\
\hline & & & $25-29,99$ & 27,3 & 36,0 \\
\hline & & & $>30$ & 0 & 24,0 \\
\hline Papon et al. (2017) [20] & Délnyugat-Franciaország & \multicolumn{4}{|l|}{$30,2 \pm 7,05$} \\
\hline Weiss et al. (2018) [21] & Románia & \multicolumn{4}{|c|}{$\begin{array}{l}\text { Az elhízás előfordulása férfiaknál } 44,9 \% \text {, nők esetében } 60,1 \% \text {. } \\
\text { Az abdominalis elhízás prevalenciája férfiaknál } 57,1 \% \text {, nőknél 81,5\% }\end{array}$} \\
\hline
\end{tabular}

$\mathrm{BMI}=$ testtömegindex

\section{Módszer}

\section{A roma populáció létszámának várható alakulása}

A cigány lakosság jelenlegi létszámát és korösszetételét a Központi Statisztikai Hivatal (KSH) 2011. évi népszámlálási adatai alapján határoztuk meg. A magyarországi cigányság várható lélekszámának előrejelzésére a demográfiai és epidemiológiai gyakorlatban széles körben alkalmazott Spectrum 5.0 szoftvert használtuk [23, 24]. A modell alkalmazásához szükségünk volt a cigányság teljes termékenységi arányszámára, a hazai cigány férfi- és női lakosság várható élettartamára a következő hatvan év tekintetében (2018-2068), az egyes korcsoportokban született gyermekek számára, továbbá a magyarországi cigány lakosság halandósági rátájának (korspecifikus halandóság) kiszámítására. A magyarországi roma populá- ció demográfiai helyzete annyira sajátos, hogy lehetetlen volt akár a korábbi magyar adatok, akár egyetlen más ország adatainak alapján prognózist készíteni. Ebből adódóan a számítások inputjául alkalmazott indikátorokat a történelmi és földrajzi analógiák alapján több országból és idősorból gyưjtöttük össze. Az egyes idősorokra trendfüggvényeket illesztettünk, és az így meghatározott értékeket alkalmaztuk a Spectrum program inputjaként.

\section{A tápláltsági állapot meghatározása}

Munkánk következő részében primer antropometriai méréseket végeztünk 18 év feletti romáknál; vizsgálatainkat öt magyarországi roma közösségben folytattuk 2015 és 2018 között. Ezek közül egy Budapesten (Pestszentlőrinc-Pestszentimre), egy Pest megyében (Bag), kettő Szabolcs-Szatmár megyében (Porcsalma és Ököri- 
tófülpös), egy pedig Tolna megyében volt (Báta). Összesen 412 fó testmagasság- és testtömegmérésére került sor; ezekből az adatokból számítottuk ki a testtömegindexet, amely a testtömeg és a testmagasság négyzetének hányadosa. A testtömeg és a testmagasság meghatározása azonos típusú kalibrált eszközökkel történt, a testmagasság mérésére milliméteres pontossággal, a testtömeg mérésére egytized kilogrammos pontossággal került sor. A testtömegindexek alapján, az Egészségügyi Világszervezet [25] ajánlásának megfelelően, a nemzetközi gyakorlattal megegyezően [26] és vizsgálataink céljával összhangban a roma lakosság tápláltsági állapotát három kategóriába soroltuk: normál $\left(18,5-24,9 \mathrm{~kg} / \mathrm{m}^{2}\right)$, túlsúlyos $\left(25,0-29,9 \mathrm{~kg} / \mathrm{m}^{2}\right)$ és elhízott $\left(\geq 30,0 \mathrm{~kg} / \mathrm{m}^{2}\right)$. A BMI alapján meghatározott tápláltsági állapot szerinti megoszlást a roma lakosság egészére vetítettük ki.

\section{Az elhizásból adódó betegségterhek meghatározása}

A cigányság körében az elhízás okozta betegségterhek előrejelzésére a Dynamic Modeling for Health Impact Assessment (DYNAMO-HIA) szoftvert alkalmaztuk [27]. A meghatározó nyugat-európai epidemiológiai kutatómúhelyek közremúködésével készült, szabadon letölthető, Markov-láncra épülő szimulációval múködő szoftver fó célja, hogy egy adott populáció alapvető jellemzőinek (életkor és nemek szerinti megoszlás) ismeretében meghatározható legyen az egyes kockázati tényezők (elhízás, dohányzás, alkoholfogyasztás) hatása a lakosság egészségi állapotára, mortalitására és morbiditására nemek és korcsoportok szerinti bontásban [28, 29]. Az algoritmus a Markov-lánc sajátos alkalmazását jelenti; a módszer lényege, hogy véletlenszerü (sztochasztikus) események bekövetkezési valószínúségeire ad becslést az esemény bekövetkeztét megelőző állapot alapján. Azaz: ha ismertjük egy populáció kitettségét egy adott kockázati tényező szempontjából, a kockázati tényező-betegség valószínűségi kapcsolatot, valamint a populáció demográfiai jellemzőit $t$ időpontban, továbbá az egyes átmeneti valószínúségek mátrixát az adott kockázati tényezők között, akkor ebből becslést adhatunk a $t+1$ időpontra, ennek alapján pedig a $t+2$ időpontra vonatkozó állapotjellemzőkre.

A modell központi eleme egy olyan adatbázis, amely a különböző kockázati tényezők - a jelen esetben az elhízás és az elhízásból adódó társbetegségek - közötti sztochasztikus kapcsolatokat tartalmazza. A DYNAMO-HIA szoftver segítségével mérhető a különböző népegészségügyi beavatkozások hatása a lakosság egészségi állapotára. A szoftver az alábbi megbetegedésekre vonatkozóan tartalmaz adatokat: ischaemiás szívbetegség, agyérbetegségek, diabetes mellitus, a tüdő rosszindulatú daganatai, szájüregi daganatok, a nyelőcső daganatai, vastag- és végbéldaganatok, emlődaganat, krónikus obstruktív tüdőbetegség. A KSH adatai szerint ezen megbetegedések az összes halálok mintegy kétharmadát teszik ki, ezért vizsgálatuk elégségesnek tekinthető az elhízás okozta megbetegedések népegészségügyi hatásainak elemzésére.

\section{Eredmények}

Munkánk első lépésében a magyarországi cigány lakosság létszámát prognosztizáltuk. Az előrejelzésben egy „alapverzióval” számoltunk, a módszertani részben bemutatott feltételezések szerint. Meg kívántuk vizsgálni a modell érzékenységét is a különböző bemeneti paraméterek változására, ezért meghatároztuk azt is, hogyan változhat a roma populáció, ha a teljes termékenységi arány 20\%-kal nagyobb, mint a számításaink alapján prognosztizált, illetve ha a cigány lakosság kezdeti lélekszáma meghaladja a KSH által közölt értéket. Eredményeinket az 1 ábra mutatja be. A roma lakosság lélekszáma mindhárom szcenárió szerint folyamatosan nő: az alapverzió alapján 2060-ra meghaladja a 450000 fót, 20\%-kal nagyobb termékenységi arány esetén pedig több mint 550000 fö lesz a magyar roma lakosság létszáma.

\section{Az elhizás prevalenciája a roma lakosság körében}

A magyarországi cigányság tápláltsági állapotát korévek és nemek szerinti bontásban a 2. ábra szemlélteti. A 1835 éves korcsoportban a BMI-átlagértékek szerint a férfiak 50,8\%-a, valamint a nók 40,6\%-a a túlsúlyos és az elhízott kategóriába tartozik. A testtömegindex-értékek alapján elmondható, hogy a 18 év feletti romáknál a túlsúly és az elhízás előfordulása a 35-64 éves korcsoport-

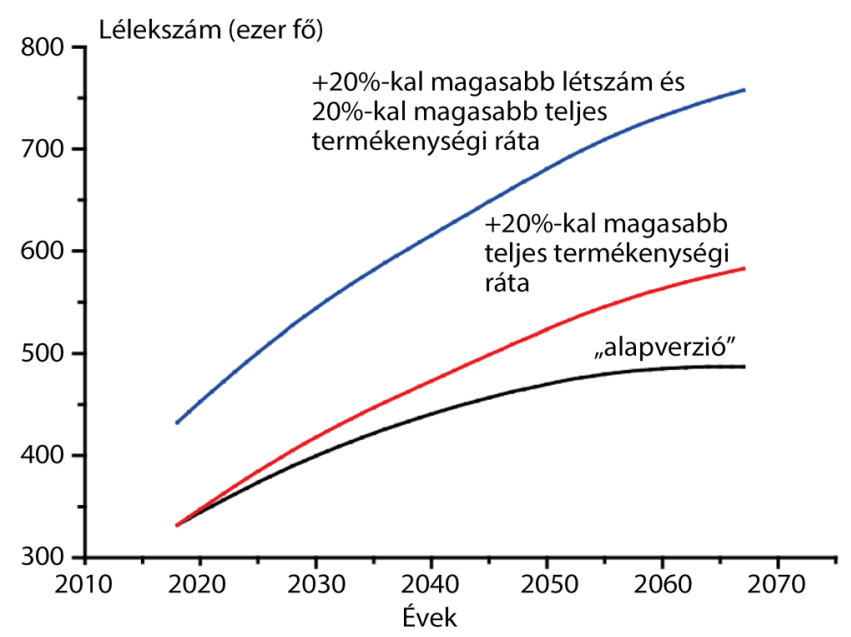

1. ábra A magyarországi cigányság létszámának várható alakulása a tanulmányban ismertetett alapverzió, az attól 20\%-kal magasabb teljes termékenységi ráta, valamint a KSH (2018) által közölthöz képest 20\%-kal magasabb lélekszám és teljes termékenységi ráta esetén

KSH $=$ Központi Statisztikai Hivatal 


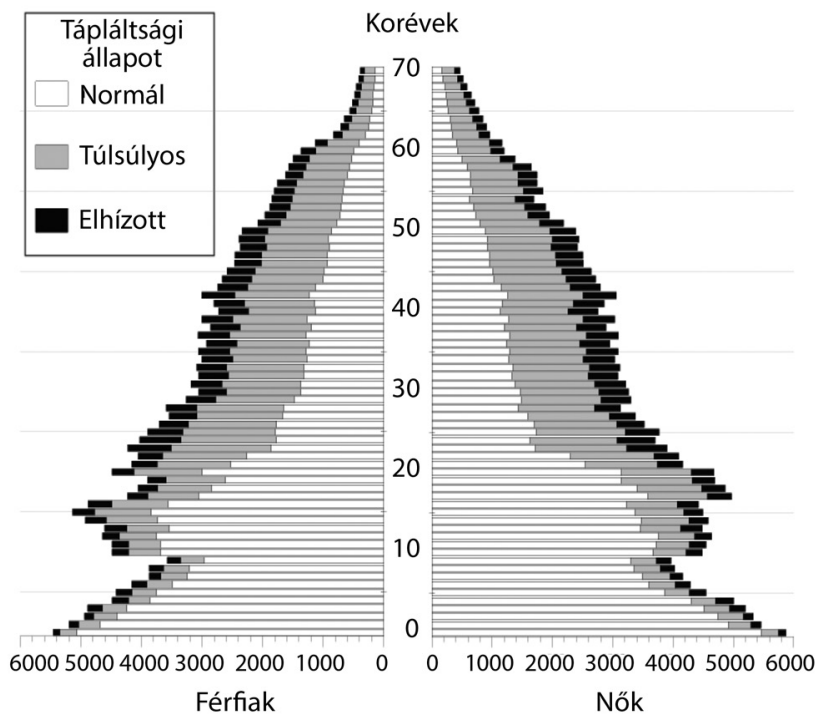

2. ábra

A magyarországi cigányság tápláltsági állapota nemek és korévek szerinti bontásban

ban a legnagyobb: a férfiak $58,3 \%$-a, a nőknek pedig a 56,7\%-a túlsúlyos és elhízott. A BMI alapján minden második $(56,4 \%)$ roma férfi és minden harmadik $(37,2 \%)$ roma nő túlsúlyos, továbbá elmondható, hogy a roma férfiak és nők közel 20\%-a szenved elhízásban.

\section{Az elhizásból adódó betegségterhek}

A DYNAMO-HIA szoftver alkalmazásával meghatároztuk a túlsúlyból és az elhízásból adódó betegségterhet a jelenlegi cigány populáció egészére vonatkoztatva. Vizsgálataink alapján a roma lakosság esetében 3-7\%-kal magasabb obesitasprevalenciával találkozunk, mint a magyarországi populáció egészére meghatározott értékek [30]. Számításaink eredményei azt igazolják, hogy az elhízás már ma is jelentős betegségterhet okoz a cigány lakosság körében. Az obesitas legfőbb társbetegségeinek az elhízásra visszavezethető preva-

2. táblázat |Az elhízás okozta többletincidencia-értékek becslése a cigány lakosság körében 2019-ben

\begin{tabular}{lrrc}
\hline Megbetegedés & Férfi & Nő & Összesen \\
\hline Ischaemiás szívbetegség & 44 & 31 & 75 \\
Agyérbetegségek & 14 & 11 & 25 \\
2-es típusú diabetes mellitus & 101 & 94 & 195 \\
Tüdődaganat & 7 & 3 & 10 \\
Vastag-és végbélrák & 3 & 1 & 4 \\
COPD & 5 & 1 & 6 \\
Emlődaganat & & 4 & 4 \\
\hline Összesen & 174 & 145 & 319 \\
\hline
\end{tabular}

COPD = krónikus obstruktív tüdőbetegség lenciája több mint 300 esetben jelentkezik már 2019ben is. Ezek közül közel kétharmadot tesz ki a diabetes mellitus aránya. A diabetes mellitus, továbbá az ischaemiás szívbetegség és az agyérbetegségek az összes, elhízásra visszavezethető főbb megbetegedés több mint 90 százalékáért felelősek. Munkánk eredményeit a 2. táblázat foglalja össze.

\section{A túlsúly és az elhizás társbetegségeinek várbató prevalenciája}

Szimulációs vizsgálataink első részében a túlsúly és az elhízás társbetegségeinek várható prevalenciáját prognosztizáltuk a következő fél évszázadra (3. ábra). Az egyes társbetegségek prevalenciájának növekedését az előrejelzési időszak első (2019-2023) és utolsó (2065-2069) öt éve között, tápláltsági állapot és nemek szerinti bontásban foglaltuk össze. Ha a jelenlegi népesség- és tápláltságiállapot-adatokat a rendkívül konzervatív (óvatos), átmeneti valószínûségek alapján kíséreljük meg előrevetíteni a következő évtizedekre, akkor azt láthatjuk, hogy az elhízáshoz kapcsolódó betegségek prevalenciája folyamatosan emelkedik: a nők esetében a következő fél évszázadban 6 ezerről 26 ezerre, a férfiaknál közel 6 ezerrôl több mint 17 ezerre nő az elhízás okozta egyéb megbetegedések száma. Ezen belül az ischaemiás szívbetegség aránya az elhízott férfiaknál a jelenlegi prevalenciaérték közel hatszorosára, nők esetében több mint háromszorosára emelkedik. Az agyérbetegségek aránya háromszor, a diabetes esetén kétszer nagyobb arányban jelentkezik majd, mint jelenleg. Minden más vizsgált betegség esetén is a jelenlegi prevalenciaértékeknek legalább a megkétszereződésével kell számolnunk. A lakosság egészére számítva az elhízás társbetegségei a férfiaknál 0,2 évvel, a nőknél 0,66 évvel csökkentik a várható élettartamot (3. táblázat).

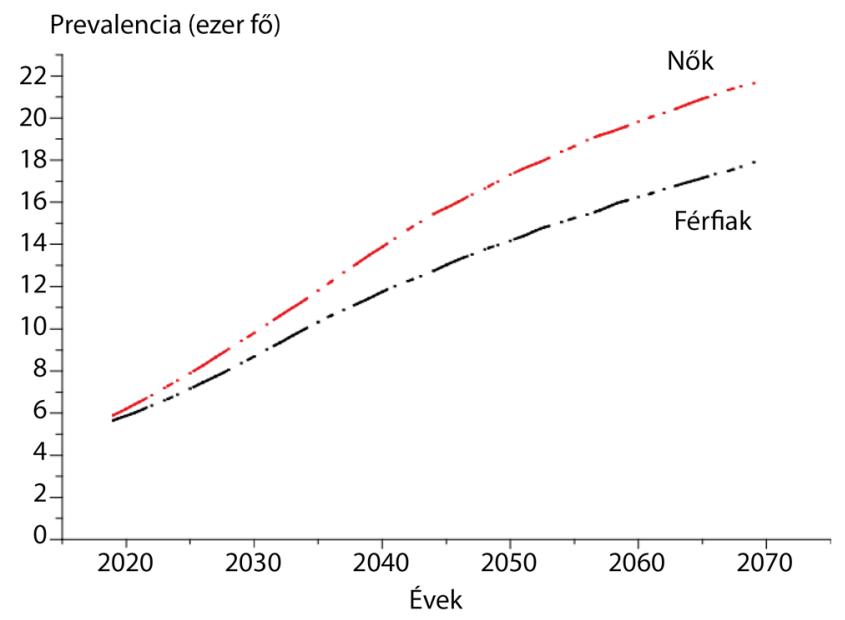

3. ábra A túlsúly és az elhízás társbetegségeinek várható prevalenciája a roma populációban 
3. táblázat | Az elhízás társbetegségeinek várható növekedési aránya a 2019-2023 és a 2065-2069 időszak között, nemek és tápláltsági állapot alapján

\begin{tabular}{|c|c|c|c|c|c|c|}
\hline & \multicolumn{3}{|c|}{ Férfi } & \multicolumn{3}{|c|}{ Nő } \\
\hline & Normál & Túlsúlyos & Elhízott & Normál & Túlsúlyos & Elhízott \\
\hline Ischaemiás szívbetegség & 2,81 & 3,87 & 5,87 & 2,89 & 3,84 & 3,12 \\
\hline Agyérbetegségek & 3,25 & 4,10 & 3,53 & 3,19 & 3,55 & 4,05 \\
\hline 2-es típusú diabetes mellitus & 2,16 & 2,28 & 2,44 & 1,71 & 2,62 & 3,24 \\
\hline Tüdődaganat & 2,75 & 4,14 & 3,38 & 1,77 & 2,37 & 4,82 \\
\hline Szájüregi daganatok & 2,83 & 3,07 & 3,70 & 2,11 & 2,89 & 4,78 \\
\hline A gége és a nyelőcső rosszindulatú daganata & 2,89 & 3,06 & 3,38 & 2,34 & 3,19 & 5,37 \\
\hline A vastag- és a végbél rosszindulatú daganata & 3,13 & 3,36 & 3,89 & 2,81 & 3,62 & 5,48 \\
\hline Az emlő rosszindulatú daganata & & & & 1,87 & 2,72 & 4,96 \\
\hline COPD & 2,47 & 2,54 & 2,92 & 2,21 & 3,10 & 5,44 \\
\hline
\end{tabular}

COPD = krónikus obstruktív tüdőbetegség

\section{Következtetések}

Munkánk eredményei azt igazolják, hogy a magyarországi roma kisebbség létszámának előrejelzése csak nagy bizonytalansággal jósolható meg, vélelmezhetóen azonban a roma lakosság létszáma meghaladja a KSH által közölt, nyolc évvel ezelőtti népszámlálási adatokat. Ebből adódóan nagy valószínúséggel a várható lakosságszám az általunk prognosztizáltnál magasabb lesz. Figyelemre méltó azonban, hogy még a leginkább óvatos (konzervatív) becslés is szigorúan monoton lakosságszám-növekedést jelez előre, ugyanakkor a roma populáció növekedésének dinamikája valamennyi prognózis szerint lassuló ütemű. Ez a tény arra is felhívja a figyelmet, hogy az egészségügyi ellátórendszer egészének a jelenleginél nagyobb mértékben kell felkészülnie a növekvő létszámú roma beteg fogadására. A növekvő számú és egyre idősödő roma lakosság ellátása mind nagyobb feladat elé állítja a hazai egészségügyet. Ezen belül az elhízás tárbetegségeinek kezelése a következő évtizedek egyik legnagyobb feladatává válik a roma lakosság körében.

A WHO a kóros elhízást 1997-ben világszerte krónikus betegségnek nyilvánította, továbbá jelentései szerint a kóros elhízás a világ legelterjedtebb, legnehezebben, legeredménytelenebbül és legnagyobb költséggel kezelhető krónikus betegsége [31]. Az elhízás mértékének növekedésével párhuzamosan a kísérőbetegségek előfordulási gyakorisága is megemelkedik. Az európai felnőtt lakosság körében az elhízás a 2-es típusú diabetes mellitus kialakulásának 80\%-áért, a hypertonia kialakulásának $55 \%$-áért és az ischaemiás szívbetegségek 35\%-áért tehető felelőssé. Ezen adatok összecsengenek a roma populációban végzett saját és nemzetközi kutatások eredményeivel [21], azonban eredményeink összevetése más kutatási eredményekkel nehézségbe ütközik a kutatásokban alkalmazott módszertani különbségek és a roma populációban az elhízás és társbetegségeinek betegségterheire vonatkozó korlátozott számú szakirodalom következtében. Az eredmények értelmezése során fontos szem előtt tartani, hogy a betegségteher változása nagymértékben befolyásolja a kezelési költségeket is. Az elhízás egészséggazdasági összetevőire is érdemes a jövőbeli elhízással kapcsolatos kutatásoknak fókuszálnia.

Kutatásunk eredményei igazolták, hogy az elhízás nagyobb részben érinti a halmozottan hátrányos helyzetú csoportok közül a roma populációt, mint a teljes magyar lakosságot, annak ellenére, hogy az Európai Unióban méréssel megállapított érték szerint az obesitas hányada Magyarországon a legnagyobb. Az elhízás kísérő betegségeinek felhalmozódása a mortalitási rizikó növekedését vonja maga után, direkt korreláció mutatható ki a várható élettartam csökkenése és a testtömegindex között. A jelen kutatásban az elhízás társbetegségei a roma férfiaknál 0,2 évvel, a roma nőknél 0,66 évvel csökkentik a várható élettartamot. A túlsúly és az elhízás nagy és egyre növekvő előfordulási gyakoriságából az következik, hogy a roma lakosság elhízásának tudományos igényü vizsgálata, az elhízás prevenciója és célzott intervenciós programok kidolgozása nagy és növekvő fontosságú népegészségügyi feladat, mert a roma lakosság létszámának jelentős arányú növekedésére kell számítanunk a következő évtizedekben [32]. Ezen túl a szakirodalomban jól dokumentált, hogy szignifikáns, pozitív korreláció igazolható a szülők és a gyermekek testtömegindexe között [33]. Ebből adódóan a romákat jellemző, kedvezőtlen tápláltsági állapot mind nagyobb tömegeket érint majd, továbbá az urbanizáció, azaz a roma lakosság városokba költözése tovább súlyosbítja a helyzetet, mert a városokban élő roma lakosság körében az elhízás mértéke még nagyobb arányú [34]. Kutatásunk eredményei a tudatos, evidenciákon alapuló prevenciós, illetve intervenciós programok bevezetésének jelentőségére hívják fel a figyelmet, a roma lakosság egészségműveltségének bővítése, az egészségben megélt életévek növelése, valamint a szociális reintegráció érdekében. Közleményünk második részében a prevenciós programok lehetséges hatásait mutatjuk be. 
Anyagi támogatás: Kiss Annának a jelen tanulmányban felhasznált DYNAMO-HIA szoftver megismerését szolgáló féléves németországi tanulmányútját a Német Katolikus Tudományos Csereszolgálat (KAAD), a kutatás megvalósítását az EFOP-3.6.3-VEKOP-16-2017-00005. számú program támogatta.

Szerzői munkamegosztás: K. A.: Kutatási koncepció, a kutatás módszertani háttere, szakirodalmi feldolgozás, primer adatgyuujtés, az adatok értelmezése, a cikk első verziójának megírása és a cikk véglegesítése. A. R., F. P.: Szakirodalmi feldolgozás, primer adatgyưjtés. L. Z.: Kutatási koncepció, a kutatás módszertani háttere, számítógépes futtatások, adatok értelmezése. A szerzők a cikk végleges változatát elolvasták és azt jóváhagyták.

Érdekeltségek: A szerzőknek nincsenek érdekeltségeik.

\section{Köszönetnyilvánítás}

A szerzők köszönetüket fejezik ki a Szent István Egyetem Élelmiszertudományi Doktori Iskolájának a kutatás lebonyolításának támogatásáért.

\section{Irodalom}

[1] European Comission. Report on the health status of the Roma population in the EU and monitoring data collection in the area of Roma health in the Member States 2014. Brussels, 2014 August. Available from: https://ec.europa.eu/health/sites/ health/files/social_determinants/docs/2014_roma_health_report_en.pdf [accessed: March 9, 2019].

[2] Anghel, IM. Contesting neoliberal governance. The case of Romanian Roma. Soc Change Review 2016; 13: 85-109.

[3] Dimitrova R, Ferrer-Wreder L. Positive youth development of Roma ethnic minority across Europe. In: Cabrera NJ, Leyendecker B. (eds.) Handbook on positive development of minority children and youth. Springer, Cham, 2017; pp. 307-320.

[4] Messing V. Methodological puzzles of surveying Roma/Gypsy populations. Ethnicities 2014; 14: 811-829.

[5] European Comission. Communication from the Commission to the European Parliament, the Council of Europe - an EU framework of national Roma integration strategies up to 2020. Brussels, 2011. Available from: https://eur-lex.europa.eu/legalcontent/HU/TXT/PDF/?uri=CELEX:52011DC0173\&from $=$ EN [accessed: March 9, 2019].

[6] FRA, UNDP, European Commission. The situation of Roma in 11 EU Member States - Survey results at a glance (2012). Publications Office, Luxembourg, p. 8. Available from: http://fra. europa.eu/sites/default/files/fra_uploads/2099-FRA2012-Roma-at-a-glance_EN.pdf [accessed: March 9, 2019].

[7] European Parliament. Resolution of 11 March 2009 on the social situation of the Roma and their improved access to the labor market in the EU (2008/2137(INI)). Strasbourg, 2009.

[8] Ciaian P, Cupák A, Pokrivčák J, et al. Food consumption and diet quality choices of Roma in Romania: a counterfactual analysis. Food Sec. 2018; 10: 437-456.

[9] Olišarová V, Tóthová V, Bártlová S, et al. Cultural features influencing eating, overweight, and obesity in the Roma people of South Bohemia. Nutrients 2018; 10: 838.

[10] Iguacel I, Fernández-Alvira JM, Labayen I, et al. Social vulnerabilities as determinants of overweight in 2-, 4-and 6-year-old Spanish children. Eur J Public Health 2018; 28: 289-295.
[11] FRANET Country thematic studies on the situation of Roma. Publications Office, Luxembourg. Available from: http://fra. europa.eu/en/country-data/2013/country-thematic-studiessituation-roma [accessed: March 9, 2019].

[12] Lizzie M. A healthcare needs assessment of the Slovak Roma community in Tinsley, Sheffield. University of Sheffield, 2010.

[13] Krajcovicova-Kudlackova M, Blazicek P, Spustova V, et al. Cardiovascular risk factors in young Gypsy population. Bratisl Lek Listy 2004; 105: 256-259.

[14] Zajc M, Narančić NS, Škarić-Jurić T. Body mass index and nutritional status of the Bayash Roma from eastern Croatia. Coll Antropol. 2006; 30: 783-787.

[15] Gallagher A, Cvorovi J, Strkalj G. Body mass index in Serbian Roma. HOMO 2009; 60: 567-578

[16] Gualdi-Russo E, Zironi A, Dallari GV, et al. Migration and health in Italy: a multiethnic adult sample. J Travel Med. 2009; 16: $88-95$.

[17] Carrasco-Garrido P, López de Andrés A, Hernández Barrera V, et al. Health status of Roma women in Spain. Eur J Public Health 2011; 21: 793-798. [Epub 2010 Oct 13]

[18] Babinska I, Veselska ZD, Bobakova D, et al. Is the cardiovascular risk profile of people living in Roma settlements worse in comparison with the majority population in Slovakia? Int J Public Health 2013 ; 58: 417-425.

[19] Zeljko HM, Škarić-Jurić T, Narančić NS, et al. Age trends in prevalence of cardiovascular risk factors in Roma minority population of Croatia. Econ Hum Biol. 2013; 11: 326-336.

[20] Papon C, Delarche N, Le Borgne C, et al. Assessment of cardiovascular risk factors in a Roma community from Southwestern France. Am J Hum Biol. 2017; 29(1): 22895. [Epub 2016 Jul 15.]

[21] Weiss E, Japie C, Balahura AM, et al. Cardiovascular risk factors in a Roma sample population from Romania. Rom J Intern Med. 2018; 56: 193-202.

[22] Kósa Z, Moravcsik-Kornyicki Á, Diószegi J, et al. Prevalence of metabolic syndrome among Roma: a comparative health examination survey in Hungary. Eur J Public Health 2015; 25: 299304. [Epub 2014 Sep 16]

[23] Stover J, Brown T, Puckett R, et al. Updates to the Spectrum/ Estimations and Projections Package model for estimating trends and current values for key HIV indicators. AIDS 2017; 31(Suppl 1): S5-S11.

[24] Avenir Health. Available from: https://www.avenirhealth.org/ software-spectrum.php 2018 [accessed: March 9, 2019].

[25] World Health Organization (WHO). BMI classification. Geneva, 2006. Available from: http://apps.who.int/bmi/index. jsp?introPage=intro_3.html [accessed: March 9, 2019].

[26] Nuttall FQ. Body mass index: obesity, BMI, and health: a critical review. Nutr Today 2015; 50: 117-128.

[27] Lhachimi SK, Nusselder WJ, Smit HA, et al. DYNAMO-HIA A Dynamic Modeling tool for generic Health Impact Assessments. PLoS ONE 2012; 7: e33317.

[28] Lhachimi SK, Nusselder WJ, Lobstein TJ, et al. Modelling obesity outcomes: reducing obesity risk in adulthood may have greater impact than reducing obesity prevalence in childhood. Obes Rev. 2013; 14: 523-531.

[29] Kulik MC, Nusselder WJ, Boshuizen HC, et al. Comparison of tobacco control scenarios: quantifying estimates of long-term health impact using the DYNAMO-HIA modeling tool. PLoS ONE 2012; 7: 32363.

[30] Erdei G, Kovács VA, Bakacs M, et al. Hungarian Diet and Nutritional Status Survey 2014. I. Nutritional status of the Hungarian adult population. [Országos Táplálkozás és Tápláltsági Állapot Vizsgálat 2014. I. A magyar felnőtt lakosság tápláltsági állapota.] Orv Hetil. 2017; 158: 533-540. [Hungarian]

[31] World Health Organization (WHO). Obesity and overweight. Geneva, 2016. Available from: http://www.who.int/mediacentre/factsheets/fs311/en/ [accessed: March 9, 2019]. 
[32] Crowe D, Kolsti J, Hancock I. (eds.) The gypsies of Eastern Europe. Routledge, London, 2016.

[33] Kumar S, Kelly AS. Review of childhood obesity: from epidemiology, etiology, and comorbidities to clinical assessment and treatment. Mayo Clin Proc. 2017; 92: 251-265.

[34] Škarić-Jurić T, Zeljko HM, Narančić NS, et al. Comparison of anthropometric indicators of obesity in rural and urban Croatian
Roma: a pilot study. Kongres preventivne medicine Promotion of anthropological science: Biological-Medical Anthropology, Anthropology of Future, 2012.

(Kiss Anna, Budapest, Villányi út 29-43., 1118 e-mail: kiss.anna891@gmail.com)

\section{"Falsus amicus obest mihi plus quam publicus hostis." \\ (A hamis barát többet árt, mint a nyílt ellenség.)}

A cikk a Creative Commons Attribution 4.0 International License (https://creativecommons.org/licenses/by/4.0/) feltételei szerint publikált Open Access közlemény, melynek szellemében a cikk bármilyen médiumban szabadon felhasználható, megosztható és újraközölhető, feltéve, hogy az eredeti szerző és a közlés helye, illetve a CC License linkje és az esetlegesen végrehajtott módosítások feltüntetésre kerülnek. (SID_1) 